\title{
Media Psychology: Challenges of Competence-Based Curricula and Employment
}

\author{
Mariam Gersamia ${ }^{1}$ and Maia Toradze ${ }^{2}$ \\ ${ }^{1}$ Professor, Ivane Javakhishvili Tbilisi State University, Georgia \\ ${ }^{2}$ Associate Professor, Ivane Javakhishvili Tbilisi State University, Georgia
}

\begin{abstract}
The purpose of this research is to identify the most common criteria (knowledge and skill-based competences) which employers consider in the process of employing media psychologists. The research holds significance for adjusting interdisciplinary educational programs and advancing media psychologists' competency matrix. The research is a valuable resource for educators in modernizing educational programs by taking into consideration employment requirements and fine-tuning accreditation standards. Employers from 35 media organizations, non-governmental and governmental organizations answered questionnaires (with close and open-ended questions).

This research answers the following questions: 1. According to what criteria could media psychologists be employed in Georgia? 2. What specific knowledge and skills are more attractive for employers?

According to the results, there is a low awareness towards media psychologists, $71 \%$ of employers do not have in staff media psychologists and up to $45 \%$ wish to employ them; and $75 \%$ of employers would offer a trail period to them.
\end{abstract}

Keywords: education, employment, Georgia, media psychology

\section{Introduction}

MEDIA psychology became a recognized branch of the American Psychological Association (APA) in the 1980s. Now, as Division 46 of the APA, media psychology is a rapidly growing interdisciplinary field. The field of media psychology is multidisciplinary and is often integrated into or overlaps with other areas of study and programs and "this list will continue to grow" [1]. Media psychologists explore the nature of the relationship between the media and human behavior, and examine this relationship on both an individual and a societal level [2]. Basically, professionals in this field study how people interact with media and each other, due to media influence. According to the "media psychology careers" this field of study can be used to determine how the media affects us and how we perceive certain elements of the media. It can also be used to determine what can be changed in media to give us a more pleasant or appropriate experience. Much of a media psychologist's job centers around the manner in which people perceive messages they see and hear on TV, the Internet, social media, radio, and other communication mediums. Today, however, media psychologists are not only concerned with television and its effects, but also all of the new media forms that have cropped up in recent years, such as the internet and cellular phone technology [3].

\section{Media Psychology And Education}

Media psychology educational programs cover topics like theories in media psychology, theories in mass communication and public relations, research methods in media psychology, social psychology, psychology of advertisement, psychology of social media strategies and marketing, political psychology and communications, persuasion and media influence, brand psychology, etc. 
Media psychologists see "the future of journalism" by referring to pro-social media (VS antisocial media) effectiveness on mental health [4, 73-74]. Media development organization "DW Akademie" has recently reported (2019) about launching a learning lab [5], the solutions journalism network's digital classroom. When media psychologists talk and promote pro-social media, they mostly refer to such solution journalism skills, e.g. whereas journalists produce solution - oriented stories; the learning lab introduces a toolkit for different topics (including covering violence, education, health issues).

Media psychology is an emerging, interdisciplinary sphere; and in Georgia, unfortunately, there is no information on how many media psychologists are employed in the media sector. The field may have a unique condition for development in the region for some rather specific reasons:

- Unique media landscape for observation: Georgian media managed to survive under omnipresent Soviet propaganda, but the legacy still looms heavily on the country's media landscape. More than 25 years after the collapse of the Soviet Union, it remains a struggle for the country to establish and maintain a favorable environment for media democracy (with a media sustainability index of 2.31, freedom of speech index 2. 54 and plurality of news 2.53 in 2018 on a scale from a low of 0 to a high of 4) [6]. Freedom House (2018) [7] scores the press freedom status as partly free and the country at 64, which is partly free as well, on a scale of 0 to 100; Reporters Without Borders (2018) ranks it 61th among 180 countries (with a score of 27.34 which means problematic) [8].

- A unique regional context creates a unique researchable area and topics, which might be attractive for international scholars. At present, Georgia is in a state of so-called hybrid war and struggles with Russian propaganda, fake news. Russia occupied $20 \%$ of Georgia's territory in 2008 . Some studies have already shown that some Georgian-language media outlets have become devices for Russian-based anti-western propaganda [9].

Describing international core competencies (so called I-COMs), Dr. Rutledge highlights: "At the core is mastery of psychological theory and an understanding of how different technologies work. Media is no longer about "mass media" but really represents mediated communication - how people send, receive, perceive and experience information and interaction using different technologies, and the impact choices of delivery has on content" [3].

\section{Media Psychology And Employment}

Media Psychologist Work in Broadcasting companies, Marketing and advertising firms, the digital marketing sphere, colleges and universities, Government, non-governmental and private research facilities; they do Independent and corporate consulting, contribute in Pubic advocacy and policy-making, research organizations, etc. According to Bernard J. Luskin [10] areas of employment and positions in 2012 included but was not limited to: Analytical and counseling companies (research positions); Non-governmental organizations focused on media and communication (research positions, consultants); PR, Marketing organizations and advertising agencies (consultants); Media-monitoring companies (research positions); Media organization: TV, Radio, online media (advertising and media firm consultant) Governmental agencies and political parties (consultants). In "Psychology Today" Luskin describes the major areas in which media psychology is fundamental is as follows: Writing about media or performing as expert guests on various media platforms; Consulting media personnel; Researching ways to improve all forms of media; Developing media standards; Studying the sociological, behavioral and psychological effects of media, etc. [10].

According to the Bureau of Labor Statistics [11] (US department of Labor), Media psychology is an incredibly fast-growing field; the Bureau states that this and similar fields are projected to grow 53\% through the year 2022: "Media-related psychology can be implemented across a vast array of industries and careers, but in general, it is the use of psychology to understand the way people utilize, create and receive various forms of media. With the technological growth the world has experienced in just the past few decades, new avenues are open today that psychologists never before imagined". According to "employment outlook \& career guidance for media psychologists" [3], because there are so many applications for media psychology, these professionals 
can be employed in a slew of different positions. Research facilities, public relations departments, advertising agencies and schools are just a few of the work places offering positions to media psychologists. The positions available to these professionals are varied and numerous;

Media psychologists have the necessary skills to pursue a career in a variety of media outlets, such as broadcasting companies (ex. television, radio, and film studios) along with marketing and advertising firms. In a marketing and advertising career, employers typically look for their psychologists to stay ahead of new trends, especially those that have to do with social media.

According to the official and latest data (2017) the unemployment rate in Georgia hits 13.9 percent, more precisely, 50.4 percent of this number refers to those between 20 and 30 . This is the precise age when students and graduates actively begin seeking jobs. The data stays high (29.6\%) among 20-24 youths [12].

According to National Assessment and Examinations Centre data and National Centre for Educational Quality Enhancement, there is no accredited undergraduate or graduate program in Media psychology in Georgia. The latter might be the reason for the former.

\section{Methodology And Procedures}

Labor market research [13, 86-93] has been used as a basis for the research in 2018 conducted in JulyAugust, 2018. Local job market research indicated that employers seek specialists with interdisciplinary competencies. 35 potential employers have been interviewed (in 2018) to identify core competencies of media psychologists requested from market, internship opportunities, position requirements, etc. The goal of the research was to find out what requirements employers have and what criteria (knowledge and skill-based competences) they might consider in the process of employing media psychologists while choosing interns and staff; what recommendations they give to the educational sector.

Qualitative and quantitative content analysis has been used for this research. A questionnaire (with open and close-ended questions) has been used as a survey instrument. The questions have a comment space/area. The number of questions is 26.

Sampling: the questionnaire was sent online to 35 employers in the capital of Georgia and its regions. The employers were chosen from nation-wide TV channels, newspapers, on-line publishers, non-governmental and research organizations focused on journalism studies, political parties;

Demographic data of the employers $(n=35): 67 \%$ from questioned respondents $(n=22)$ are female, $33 \%$ $(\mathrm{n}=11)$ male ( 2 refused to answer). According to age, the highest percentage goes to the questioned respondents from 26 to $55(82 \% \mathrm{n}=27)$, under 26-12\% $(\mathrm{n}=4)$ and over $56-6 \%(\mathrm{n}=2)$.

Employers from 35 answered questionnaires (with close and open-ended questions). Among them $51 \%$ $(\mathrm{n}=17)$ were from private companies (TV, radio, online and research organizations), 27\% ( $\mathrm{n}=9$ ) from nongovernmental organizations, $9 \%(n=3)$ from governmental sector and $12 \%(n=4)$ from political parties. 2 respondents refused to answer this question. According to the preliminary agreement, the questionnaire was completed by those high ranking managers who are in charge of employing new people or selecting them for internship.

Research questions are as follows: According to what criteria could media psychologists be employed in Georgia? (1), and what specific knowledge and skills are more attractive for employers? (2).

\section{Main Findings}

The research answered the abovementioned questions. Majority of respondents (82\%) answer, that knowledge and skill based competencies with emphasis on psychology is critically important (61\%) or important (21\%) for journalists; $88 \%$ of employers think that media employees should be ethical (reduce stigmatization and strengthening stereotypes, no use of hate speech, etc.); they should have a good understanding of the negative and positive phenomena/effects of Media (TV, Radio, Print and online) product; 
Lange [14] highlights that considering the fact that graduates also seek self-employment, graduate's values, authonomy and responsibility should also become vital for self-realization. As to the employers in Georgia, they say that graduates should be able to improve their knowledge independently. In addition, $33 \%$ mentions that graduates lack of responsibility skills and highlight this as a fault of educational programs.

According to the results, $71 \%$ of employers do not have in staff media psychologists and up to $45 \%$ wish to employ specialists with such competencies; there is a low awareness about the media psychology filed in general and $39 \%$ still do not know if they want to employ them in Georgia. Despite this fact, $75 \%$ of employers would offer a trail period to them. In a previous study [13] it was highlighted, that $52 \%$ of employers prioritize a profound knowledge in a specific field (besides journalism). It is worth mentioning that $84 \%$ of respondents give preference to the competences gained in specific fields such as economy, politics, arts, etc. In the survey (2018) respondents indicate, that a weakness of the higher educational system is that graduates do not have interdisciplinary knowledge and skills (39\%).

The respondents have answered the question: "what position would you offer to specialists with media psychologists' competencies?” Here, employers could give multiple answers (up to 3 choices). According to the answers, they would be glad to offer to media psychologists the same positions mentioned above by international scholars and these positions in Georgia are as follows: Journalists (who work in hot places, cover children issues and violence, conflicts, psychology, etc.) - $27 \%$; producers, editors, producer assistants $-18 \%$, marketing specialist $-21 \%$, consultant $-18 \%$, researcher $-21 \%$; Specialist in PR and media relations department - 15\%; 6\% - answered that there is no need for such specialist; $6 \%$ - Depends on specific competencies. One respondent specified, that she "would be glad to offer the position of producer to a media psychologist so she/he could supervise entry-level journalists and interns".

As to the RQ 2 ("What specific knowledge and skills are more attractive for employers?"), respondents have produced recommendations for improvement of competence based education via the following descriptors: Knowledge and understanding, applying knowledge, autonomy and responsibility. In particular, employers wish to improve knowledge in media ethics, knowledge in using new technologies, knowledge in usage of new social media platforms, having necessary skills for managing stress and deadlines, etc. In their opinion, media psychologists' skills are vital for practitioner journalists as well. They need to know how to deal with stress, they should be aware of psychology. They should know how negative phenomena works, how fake, biased news and propaganda effects the minds people and their perception of reality. So these recommendations refer to journalism curricula as well);

Employers suggest paying more attention to topics covering: Media influence on audiences, persuasive techniques, creating public opinion via media. Research showed that for the majority of our employers, practical skills are important. They suggest enhancing interdisciplinary teaching and popularization of the media psychology field, and raise awareness of media literacy and media psychology. In their opinion, media psychologists' skills are vital for practitioner journalists as well. They need to know how to deal with stress, and they should be aware of psychology. They should know how negative phenomena works, how fake, biased news and propaganda effects the minds of people and their perception of reality.

According to employer opinion, the students at Universities gain more theoretical knowledge than practical. For the majority, practical knowledge is essential. Answering the question about weaknesses of University's educational programs, the employers could choose more than one option. In "top three weaknesses" we've got, that graduates do not have practical skills (79\% out of 100), autonomy/initiatives (46\% out of 100) and interdisciplinary knowledge and skills (39\% out of 100).

We have summarized these recommendations and the best practices in media psychology sphere and suggested the core competencies for graduate level (See table I).

TABLE I: the core competencies for media psychologist

learning outcomes regarding "Knowledge and understanding" descriptor

PL $\quad$ Gain in-depth and systematic knowledge of psychological antecedents 


\begin{tabular}{|c|c|c|}
\hline $\mathrm{O} 1$ & & $\begin{array}{l}\text { and consequences of media use, influence, effects and functioning of } \\
\text { media audiences (including minorities, members of understudied and/or } \\
\text { marginalized groups); }\end{array}$ \\
\hline $\mathrm{O} 2$ & PL & $\begin{array}{l}\text { Gain in-depth and systematic knowledge about the process of } \\
\text { interaction between media (social media included) and the influence of } \\
\text { new technologies on human behavior; }\end{array}$ \\
\hline O 3 & PL & $\begin{array}{l}\text { Gain systematic knowledge of research methods in media psychology } \\
\text { and communications; }\end{array}$ \\
\hline $\mathrm{O} 4$ & PL & $\begin{array}{l}\text { Understand the role of critical thinking, media and digital literacy } \\
\text { (MIDL) in the development of society, individuals and media } \\
\text { environment. }\end{array}$ \\
\hline O 5 & PL & $\begin{array}{l}\text { Understanding what it means to be a global citizen, which is now a } \\
\text { benchmark of personal growth and career readiness [15]. }\end{array}$ \\
\hline \multicolumn{3}{|r|}{$\begin{array}{c}\text { Program learning outcomes regarding "Practical Application of the } \\
\text { Theoretical Knowledge" }\end{array}$} \\
\hline O 6 & PL & $\begin{array}{l}\text { Identify key concepts, theories and research paradigms (principles and } \\
\text { methods), application of theories to real life situations. }\end{array}$ \\
\hline O 7 & PL & Utilize appropriate research methodologies and procedures \\
\hline $\mathrm{O} 8$ & PL & $\begin{array}{l}\text { Apply a broad range of relevant media psychological knowledge when } \\
\text { providing recommendations backed with research. Analyze various } \\
\text { moral and ethical dilemmas that arise within the media and media } \\
\text { psychology as a science; Analyze critically media product and } \\
\text { contribute in developing media standards; }\end{array}$ \\
\hline PLO 9 & & Use ICTs for professional and scientific purposes \\
\hline \multicolumn{3}{|r|}{$\begin{array}{c}\text { Program learning outcomes regarding "Autonomy and responsibility" } \\
\text { descriptor }\end{array}$} \\
\hline PLO 10 & & $\begin{array}{l}\text { Use life-long learning skills in order to further pursue an academic } \\
\text { career, develop and distribute knowledge (in academic and non- } \\
\text { academic society); to organize own learning, including through } \\
\text { effective management of time and information, both individually and in } \\
\text { groups [16]. }\end{array}$ \\
\hline PLO 11 & & $\begin{array}{l}\text { Follow the professional and academic norms of ethics and practice } \\
\text { academic integrity. }\end{array}$ \\
\hline PLO 12 & & $\begin{array}{l}\text { Respect for human rights, cultures (e.g. beliefs, values, practices and } \\
\text { behaviors), languages and sensitivity to diversity; readiness to respect } \\
\text { for diversity and values of others [17]. }\end{array}$ \\
\hline
\end{tabular}

\section{Conclusions And Recommendations}

Even from a single glance, it is visible, that local, international media and emerging technologies (social media included) can have an influence on media consumers, human behavior, voters, political and cultural landscapes. Media can actually tell us what to think about and how to construct frames in our mind [18] and in our opinion, media psychologists can contribute in adjusting media standards, accelerate media transformation and influence attitudes and values. This particularly refers to countries with new/young democracies (like Georgia), because media consumers from the post-soviet society might be more vulnerable to propaganda, negative phenomena in media and fake news effects. On one hand, Post-soviet society and media are in the process of a unique transformation and democratization. On the other hand, there is lack of studies that evaluate the influence of various factors on media consumers. There is a gap in terms of research being conducted into media psychology in Georgia. Media psychologists might have a unique role to play in the process of media transformation. That is why it is more important to provide the marketplace with media psychologists who will have enough competence to provide people in the media field with high-quality recommendations and 
consultations. The launching of accredited programs and updated set of international competencies (I-COMs: core competencies) could definitely contribute to popularization of this filed in Georgia. Survey results have already been taken into consideration by academia and a Master program (media psychology and communications) at Tbilisi State University, and has been adjusted according to those recommendations. In addition, internship credit-courses have been embodied in curricula.

Popularization of this field is a challenge in Georgia and in this regard, competence-based educational programs can open new perspectives to media psychologists and create a new niche for employment.

\section{References}

[1] American Psychological Association (APA) web-site, division 46: Society for media psychology and technologies, www.apadivisions.org/division-46/resources/graduate/index.aspx (last visited Dec, 2018).

[2] Psychology school guide, www.psychologyschoolguide.net (last visited Aug., 2018).

[3] Media psychology careers, www.careersinpsychology.org/becoming-a-media-psychologist/ (last seen Aug., 2018)

[4] Giles, Media psychology, LEA, publishers, 2003

[5] Solutions Journalism Network, Learning Lab, the Solutions Journalism Network's digital classroom, www.learninglab.solutionsjournalism.org, (last seen, Jan., 2019)

[6] Media Sustainability Index 2018, country report - Georgia, IREX www.mediasustainabilityindex.org/?country=GE\&year=2018, (last seen Jan., 2019)

[7] Freedom House, country profile 2018 (Georgia), www.freedomhouse.org/report/freedom-world/2018/georgia , (last seen Jan., 2019)

[8] Reporters Without Borders, 2018 World Press Freedom Index, www.rsf.org/en/ranking, (last seen Jan., 2019)

[9] Media development Foundation, Anti-Western 2018 www.mdfgeorgia.ge/uploads/library/89/file/eng/AntiWest-2017-ENG.pdf, (last seen Jan., 2019)

[10] Bernard Luskin, Defining and Describing Media Psychology, Media psychology: A blend of psychology and conventional wisdom, Psychology Today, https://www.psychologytoday.com (last seen Aug., 2018)

[11] Bureau of Labor Statistics, U.S. Department of Labor, Occupational Outlook Handbook, Psychologists, www.bls.gov/ooh/life-physical-and-social-science/psychologists.htm (last seen Dec., 2018)

[12] National Statistics office of Georgia, employment and unemployment www.geostat.ge/index.php?action=page\&p_id=146\&lang=eng (last seen Dec., 2018)

[13] Gersamia M., Toradze M., Employment of Entry Level Journalists: Case of Georgia, European Journal of Multidisciplinary Studies, Jan-Apr. 2018, Vol. 7, Nr. 2, p. 86-93

https://doi.org/10.26417/ejms.v7i2.p86-93

[14] Thomas Lange, Job satisfaction and self-employment: autonomy or personality? Small Business Economics, Vol. 38, No. 2 (February 2012), pp. 165-177, Stable URL: www.jstor.org/stable/41410010, (last seen Dec., 2018)

[15] National communication association, internationalizing the communication discipline, https://www.natcom.org/academic-professional-resources/internationalization, (last seen Jan., 2019)

[16] The Key Competences for Lifelong Learning - A European Framework, European commission staff working document, Accompanying the document Proposal for a COUNCIL RECOMMENDATION on Key Competences for Life Long Learning, 2006, Brussels, www.eur-lex.europa.eu/legalcontent/EN/TXT/PDF/?uri=CELEX:52018SC0014\&from=EN (last seen Jan., 2019)

[17] Developing media literacy and critical thinking through education and training, Council of the EU, Brussels, 2016

[18] Maxwell E. McCombs and Donald L. Shaw, The Agenda-Setting Function of Mass Media, The Public Opinion Quarterly, Vol. 36, No. 2 (Summer, 1972), pp. 176-187, Oxford University Press, http://www.jstor.org/stable/2747787 [last seen Feb, 2019]. 
First Author, Mariam Gersamia is a professor, media psychologist at Ivane Javakhishvili Tbilisi State University (TSU, Georgia); She got her doctoral degree in journalism studies (2004) and post-diploma education in body-oriented psychology (2018). With 19 years of experience in academia, she used to be a head of journalism and mass communication department (at TSU), head of undergraduate, graduate and doctoral programs. She has background in NGO sector, public relations sphere and political communications. She is an accreditation expert (since 2011). She is a head of NGO "media and communication educational and research center (MCERC)". Her major filed of studies are: media psychology, public relations, media education.

Second Author Maia Toradze is an associated professor at at Ivane Javakhishvili Tbilisi State University (TSU, Georgia); She got her doctoral degree in journalism studies (2006). She is an editor and co-author of 13 books. With 30 years of experience in journalism, nowadays, she has is a deputy editor at "Tbilisi University" newspaper; She is a member of NGO "media and communication educational and research center (MCERC)". Her major filed of studies are: print media, media literacy, media psychology. 